\title{
KORELASI PEMERIKSAAN GLUKOSA URIN DENGAN PROTEIN URIN PADA PENDERITA DIABETES MELLITUS TIPE II DI RSUD dr. H. ABDUL MOELOEK PROVINSI LAMPUNG
}

\author{
Azhari Muslim \\ Jurusan Analis Kesehatan Poltekkes Tanjungkarang \\ Email: azhariaja6@gmail.com
}

\begin{abstract}
Correlation Glucose of Urine and Protein of Urine in Sufferer of Diabetes Mellitus Type II in RSUD dr H Abdul Moeloek Provinsi Lampung. Diabetes mellitus is metabolic disorder with hyperglicaemia sign caused by descent of activity and or quantity of insulin is caused by defect of pankreas. In fisiologic condition, pankreas produces insulin for carbohydrate metabolism in our meal. Descent activity of insulin causes defect of karbohydrat, lipid, water and electrolite. WHO says Indonesia has fourth ranking of diabetes mellitus sufferer in the word with prevalence about $8,6 \%$. Ministry of health said amount of diabetes mellitus sufferer has first ranking of endokrin disease. This study has aim correlation concentration of glucose urine and protein urine in diabetes mellitus type II. This research is cross sectional. Dependent variable is protein urine concentration and independent variable is glucose urine concentration. Outcome of this study shows correlation betwen glucose urine concentration and protein urine concentration in diabetes mellitus type II sufferer with $\mathrm{p}=0,003$ and power of correlation is perfect of possitive linier about $\mathrm{r}=1.000$. It means if concentration of urine glucose is increase followed by concentration of protein urine is higher. Influence of glucose urine concentration for increase protein urine can predict with formula $Y=416,77-236 \mathrm{X}$, where $\mathrm{X}$ is concentration of urine glucose and $\mathrm{Y}$ is concentration of protein urine. It is necessary to protein urine examination and more specific research to link protein urine as a marker of nefropaty diabetic.
\end{abstract}

Keywords: Glucose of urine, Protein of urine, Diabetes Mellitus

\begin{abstract}
Abstrak: Korelasi Pemeriksaan Glukosa Urin Dengan Protein Urin Pada Penderita Diabetes Mellitus Tipe II di RSUD dr. H. Abdul Moeloek Provinsi Lampung. Diabetes mellitus (DM) merupakan kelainan metabolik yang ditandai oleh hiperglikemia karena penurunan efektivitas dan atau jumlah insulin, akibat gangguan pankreas. Pada keadaan normal, pankreas memproduksi insulin untuk metabolisme karbohidrat yang terkandung dalam makanan yang kita makan. Penurunan aktivitas dan atau jumlah insulin menyebabkan gangguan metabolisme karbohidrat, lemak, air dan elektrolit. $W H O$ menyatakan bahwa Indonesia menempati urutan keempat terbesar dalam jumlah penderita DM dengan prevalensi 8,6\% dari total jumlah penduduk. Departemen Kesehatan menyebutkan bahwa jumlah pasien rawat inap maupun rawat jalan di rumah sakit dengan diabetes melitus menempati urutan pertama dari seluruh penyakit endokrin. Penelitian ini bertujuan untuk mengetahui korelasi pemeriksaan kadar glukosa urin dengan protein urin pada penderita diabetes mellitus tipe II. Penelitian ini merupakan potong lintang untuk mengetahui korelasi kadar glukosa urin dengan protein urin. Variabel terikat pada penelitian ini adalah kadar protein urin, sedangkan variabel bebas adalah kadar glukosa urin. Hasil penelitian menunjukkan terdapat korelasi antara kadar glukosa urin dengan kadar protein urin pada penderita diabetes mellitus tipe II dengan korelasi/hubungan $\mathrm{p}=0,003$ dan kekuatan korelasi adalah linier positif sempurna sebesar $\mathrm{r}=1.000$. Hal ini berarti kenaikan kadar glukosa urin diikuti kenaikan kadar protein urin. Prediksi besarnya pengaruh kadar glukosa urin dalam meningkatkan kadar protein urin menggunakan persamaan $\mathrm{Y}=416,77-236 \mathrm{X}$, dimana $\mathrm{X}$ adalah kadar glukosa urin dan $\mathrm{Y}$ adalah kadar protein urin. Perlu dilakukan pemeriksaan protein urin dan penelitian yang lebih spesifik berkaitan dengan protein urin sebagai marker untuk pencegahan kejadian nefropati diabetika.
\end{abstract}

Kata kunci: Glukosa urin, Protein urin, Diabetes Mellitus

Diabetes mellitus (DM) merupakan kelainan metabolik yang ditandai oleh hiperglikemia karena penurunan efektivitas dan atau jumlah insulin, akibat gangguan pankreas.
Pada keadaan normal, pankreas memproduksi insulin untuk metabolisme karbohidrat yang terkandung dalam makanan yang kita makan. Penurunan aktivitas dan atau jumlah insulin 
menyebabkan gangguan metabolisme karbohidrat, lemak, air dan elektrolit. (Moerdowo, 2002)

Menurut survey Word Health

Organization (WHO), Indonesia menempati urutan ke 4 terbesar dalam jumlah penderita Diabetes Melitus (DM) dengan prevalensi 8,6\% dari total jumlah penduduk. Data Departemen Kesehatan menyebutkan bahwa jumlah pasien rawat inap maupun rawat jalan di rumah sakit dengan Diabetes Melitus menempati urutan ke 1 (pertama) dari seluruh penyakit endokrin. (Perkeni, 2006)

Penelitian berbagai tempat di Indonesia sering terjadi peningkatan prevalensi Diabetes Melitus yang cukup tinggi, hal ini berhubungan dengan adanya peningkatan taraf hidup dan kemakmuran, perubahan pola hidup dan pola makan yang berlebihan sehingga dapat menyebabkan gangguan metabolisme. Hiperglikemia pada Diabetes Melitus berhubungan dengan kerusakan jangka panjang, disfungsi atau kegagalan beberapa organ tubuh. Adanya gangguan terutama pada sistem metabolisme karbohidrat, lemak dan protein di dalam tubuh, gangguan tersebut disebabkan karena kurang produksi hormon insulin yang diperlukan dalam proses perubahan gula menjadi tenaga dan sintesa lemak. Bila terjadi gangguan pada kerja insulin, baik secara kualitas maupun kuantitas keseimbangan tersebut akan terganggu dan kadar glukosa darah akan meningkat, kelebihan glukosa akan dikeluarkan melalui urin sehingga terjadi glukosuria (Guyton, 2007; Depkes RI, 2009).

Salah satu komplikasi akibat DM adalah nefropati diabetika (ND). Nefropati diabetika adalah penyebab utama gagal ginjal stadium akhir. Saat ini, ND terjadi pada $15-25 \%$ pasien DM tipe I dan $30-40 \%$ pasien DM tipe 2 (Schrijvers et al, 2004).

Berbagai data hasil penelitian memperkirakan bahwa protein urin merupakan nilai sebagai indeks kerusakan vaskuler, yang merupakan manifestasi peningkatan kadar glukosa urin terutama pada diabetes mellitus (Bloomgarden ZT, 2005)

Berdasarkan survei yang dilakukan pada beberapa Rumah Sakit, Puskesmas dan laboratorium klinik khususnya di RSUD dr. H Abdul Moeloek Provinsi Lampung. Pemeriksaan kadar protein urin tidak dilakukan walaupun hasil pemeriksaan kadar glukosa urin melebihi batas ambang normal. Berdasarkan hasil penelitian Bloomgarden ZT, 2005, menunjukkan bahwa protein urin merupakan indeks kerusakan vaskuler sebagai manifestasi peningkatan kadar glukosa urin.

Tujuan umum penelitian ini adalah untuk mengetahui apakah ada korelasi pemeriksaan glukosa urin (glukosuria) dengan protein urin pada penderita Diabetes Melitus tipe II di RSUD dr. H. Abdul Moeloek Provinsi Lampung.

Manfaat penelitian ini secara teoritis adalah untuk pengembangan keilmuan di bidang teknologi laboratorium medik dan untuk menambah khasanah kajian ilmiah di bidang kimia klinik. Sedangkan manfaat aplikatif adalah penelitian ini diharapkan dapat memberikan manfaat bagi masyarakat untuk melakukan pemeriksaan laboratorium rutin yaitu pemeriksaan glukosa urin dan protein urin sehingga penderita diabetes melitus tipe II dapat terkontrol dengan baik. Untuk instansi laboratorium klinik, untuk dapat memasukkan pemeriksaan protein urin ke dalam pemeriksaan kimia klinik untuk penderita diabetes mellitus tipe II.

Berdasarkan uraian di atas, peneliti ingin melakukan penelitian mengenai Korelasi Pemeriksaan Glukosa Urin (Glukosuria) dengan protein urin pada penderita diabetes melitus tipe II.

\section{METODE PENELITIAN}

Penelitian ini adalah penelitian metode analitik dengan studi potong lintang (cross sectional) untuk mengetahui korelasi pemeriksaan glukosa urin dengan protein urin pada penderita diabetes melitus tipe II (Sudigdo, et al, 2011).

Penelitian ini adalah pasien dengan diabetes melitus tipe II yang sesuai dengan kriteria The Expert Committee on Diagnosis and Classification dengan glukosuria yang menjalani pemeriksaan di Laboratorium Patologi Klinik di RSUD Dr. H. Abdul Moeloek Provinsi Lampung.

Perhitungan perkiraan besar sampel dengan menggunakan dasar ketepatan relatif. (Sudigdo, 2011).

Rumus yang digunakan dalam penelitian ini adalah :

$$
\begin{aligned}
& n=\left[\frac{z_{\alpha} \times s}{e_{x} \times x_{0}}\right]^{2} \\
& n=\left[\frac{1,96 \times 10}{0,05 \times 80}\right]^{2}=24
\end{aligned}
$$


Dengan simpangan baku populasi standar, $\mathrm{Z} \alpha=$ 1,96 ; tingkat ketepatan relatif yang diperkenankan, $\mathrm{e}_{\mathrm{x}}=5 \%$; simpangan baku, $\mathrm{s}=10$; nilai rerata populasi standar, $\mathrm{x}_{0}=80$.

Besar sampel minimal yang dibutuhkan dalam penelitian ini adalah 24 , dengan perkiraan drop out sebesar $10 \%$ maka besar sampel yang dibutuhkan minimal adalah 27 responden. Besar sampel dalam penelitian ini adalah 51 subyek penelitian (Sudigdo, 2011).

Penelitian dilaksanakan di Laboratorium Patologi Klinik RSUD Dr. H. Abdul Moeloek Provinsi Lampung.

Penelitian ini adalah menggunakan urin glukosuria, glukosa urin positif 3 dan glukosa urin positif 4 pada penderita Diabetes Melitus tipe II yang menjalani pemeriksaan di Laboratorium Patologi Klinik RSUD Dr. H. Abdul Moeloek Provinsi Lampung.

Variabel terikat pada penelitian ini adalah kadar protein urin sedangkan variabel bebas adalah kadar glukosa urin.

Cara pengumpulan data penelitian ini adalah dengan metode purposive sampling, dimana setiap pasien yang memenuhi kriteria penelitian yaitu pasien dengan Diabetes Melitus tipe II yang menjalani pemeriksaan urin dengan glukosuria (kadar glukosa urin positif 3 dan 4) dimasukkan ke dalam penelitian ini sehingga jumlah populasi dan sampel penelitian terpenuhi, selanjutnya dilakukan pemeriksaan kadar protein urin.

Pemeriksaan kadar protein urin menggunakan instrumen Urine analyzer Combi Scan 500 dan reagen berupa stick yaitu Combi screen II sys plus dengan bahan pemeriksaan urin sewaktu. Prosedur kerja dengan tahapan menekan tombol working, menekan no ID yang akan diperiksa, menekan enter, kemudian menekan quick dua kali, menekan start, memasukkan strip urin ke dalam alat serta menunggu hasil pemeriksaan selama 60 detik (Gandasubrata, 2004; Mengko, 2013)

Analisis data diawali dengan pemasukan (Entry) data, Editing, Coding dan Cleaning, setelah itu dilakukan analisis secara univariate untuk memperoleh gambaran pada masingmasing variabel bebas. Teknik analisis data statistik uji korelasi Pearson glukosa urin dengan protein urin pada penderita Diabetes Melitus Tipe II, menggunakan $\alpha=0,05$ dengan tingkat kepercayaan 95\% (Hastono, SP, 2007)

\section{HASIL PENELITIAN}

\section{Analisis Univariat}

Tabel 1. Kadar Glukosa Urin pada Penderita Diabetes Mellitus Tipe II

\begin{tabular}{clc}
\hline No & \multicolumn{1}{c}{ Kadar Glukosa Urin } & Jumlah \\
\hline 1 & $\begin{array}{l}250 \mathrm{mg} / \mathrm{dL} \mathrm{s} / \mathrm{d}<500 \\
\mathrm{mg} / \mathrm{dL}\end{array}$ & 23 \\
\hline 2 & $500 \mathrm{mg} / \mathrm{dL} \mathrm{s} / \mathrm{d} 1000 \mathrm{mg} / \mathrm{dL}$ & 28 \\
\hline
\end{tabular}

Tabel 1 menunjukkan subyek penelitian dengan kadar glukosa urin antara $250 \mathrm{mg} / \mathrm{dL}$ s/d $<500 \mathrm{mg} / \mathrm{dL}$ sebanyak 23 orang. Sedangkan kadar glukosa urin antara $500 \mathrm{mg} / \mathrm{dL}$ s/d 1000 $\mathrm{mg} / \mathrm{dL}$ sebanyak 28 orang.

Tabel 2. Kadar Protein Urin Pada Penderita Diabetes Mellitus Tipe II

\begin{tabular}{ccc}
\hline No & Kadar Protein Urin & Jumlah \\
\hline 1 & Negatif s/d $30 \mathrm{mg} / \mathrm{dL}$ & 0 \\
\hline 2 & $>30 \mathrm{mg} / \mathrm{dL} \mathrm{s} / \mathrm{d} 100 \mathrm{mg} / \mathrm{dL}$ & 20 \\
\hline 3 & $>100 \mathrm{mg} / \mathrm{dL} \mathrm{s} / \mathrm{d} 500 \mathrm{mg} / \mathrm{dL}$ & 31 \\
\hline
\end{tabular}

Tabel 2 menunjukkan subyek penelitian dengan kadar protein urin antara negatif s/d 30 $\mathrm{mg} / \mathrm{dL}$ sebanyak 0 orang. Kadar protein urin antara $>30 \mathrm{mg} / \mathrm{dL} \mathrm{s} / \mathrm{d} 100 \mathrm{mg} / \mathrm{dL}$ sebanyak 20 orang. Sedangkan kadar protein urin antara $>100$ $\mathrm{mg} / \mathrm{dL} \mathrm{s} / \mathrm{d} 500 \mathrm{mg} / \mathrm{dL}$ sebanyak 31 orang.

\section{Analisis Bivariat}

Analisis bivariat menggunakan uji korelasi Pearson dengan program komputer. Berikut ini tabel pengolahan data bivariat dengan program komputer :

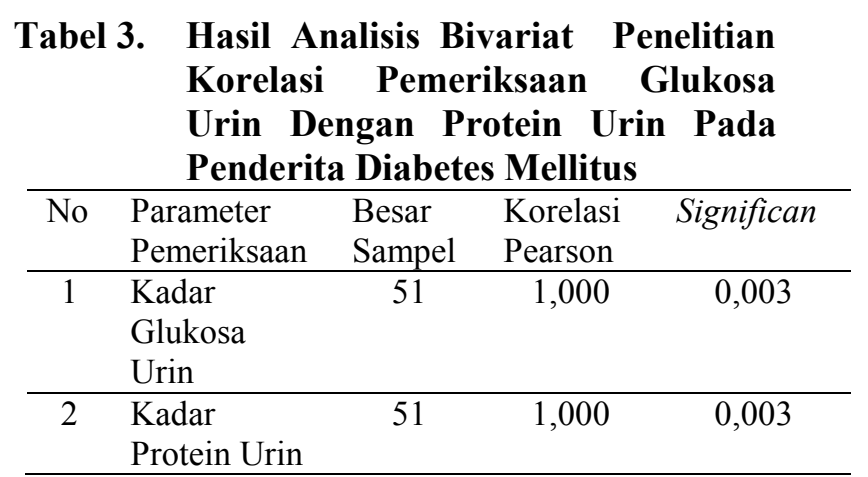

Berdasarkan tabel 3 di atas terlihat bahwa terdapat korelasi kadar glukosa urin dengan protein urin ada penderita diabetes mellitus tipe II dengan signifikansi 1 ekor $=0,003$.

Kekuatan hubungan (korelasi Pearson) didapatkan sebasar 1,000. Menurut Colton, 
kekuatan hubungan dua variabel adalah sangat kuat/ sempurna (Hastono, SP, 2008).

Tabel 4. Nilai Regresi Linier Penelitian Korelasi Pemeriksaan Glukosa Urin dengan Protein Urin pada Penderita Diabetes Mellitus Tipe II

\begin{tabular}{clrc}
\hline No & \multicolumn{1}{c}{ Model } & Koefisien B & Significan \\
\hline 1 & Konstanta & 416,766 & 0,000 \\
\hline 2 & $\begin{array}{l}\text { Kadar } \\
\text { Glukosa Urin }\end{array}$ & -236 & 0,026 \\
\hline
\end{tabular}

Berdasarkan tabel 4 di atas, dapat disimpulkan bahwa persamaan $\mathrm{Y}=416,77-236$ $\mathrm{X}$ dapat digunakan untuk memprediksi besarnya pengaruh kadar glukosa urin dalam meningkatkan kadar protein urin. Dimana $\mathrm{X}$ adalah kadar glukosa urin dan $\mathrm{Y}$ adalah kadar protein urin (Hastono SP, 2008).

\section{PEMBAHASAN}

Data analisis bivariat menunjukkan bahwa antara kadar glukosa urin dengan protein urin terdapat korelasi/hubungan dengan $p=0,003(p<$ 0,05 ) dengan kekuatan korelasi yaitu: $r=1.000$ berarti terdapat hubungan linier positif sempurna. Hal ini berarti kenaikan kadar glukosa urin diiikuti kenaikan kadar protein urin. Sedangkan pada regresi linier didapatkan persamaan $\mathrm{Y}=$ 416,77-236 $X$ dapat digunakan untuk memprediksi besarnya pengaruh kadar glukosa urin dalam meningkatkan kadar protein urin, dimana $\mathrm{X}$ adalah kadar glukosa urin dan $\mathrm{Y}$ adalah kadar protein urin (Hastono SP, 2008).

Hal ini sesuai dengan penelitian yang dilakukan oleh Ritz E, et al (2000) yang menyatakan bahwa pada penderita diabetes mellitus yang menahun terjadi kerusakan pada pembuluh darah halus di ginjal. Kerusakan pembuluh darah menimbulkan kerusakan glomerulus yang berfungsi sebagai penyaring darah. Tingginya kadar glukosa akan membuat struktur ginjal berubah sehingga fungsinya terganggu yang mengakibatkan protein/ albumin dapat melewati glomerulus sehingga protein/ albumin dapat ditemukan di dalam urin.

Diabetes melitus dapat menyebabkan komplikasi vaskuler. Penelitian sebelumnya menunjukkan adanya pengaruh khusus secara seluler pada ginjal dengan hiperglikemia yang terletak pada aktivasi RAS secara lokal di dalam ginjal sebagai penyebab kerusakan jaringan. Penemuan yang terbaru mengenai G-protein coupled receptor (GPR91) yang diaktifkan oleh hasil nilai tengah siklus asam sitrat yaitu suksinat, mendorong penemuan hubungan antara kadar glukosa yang tinggi dengan pelepasan renin dari juxtaglomerular apparatus (JGA) pada ginjal (Peterdi, 2008).

Kadar glukosa darah yang tinggi berhubungan dengan peningkatan transforming growth factor $\beta$ (TGF $\beta$ ) dan peningkatan ekstracelular matrics (ECM), semuanya berhubungan dengan nefropati diabetik. Perubahan pada glomerulus pada ginjal mengakibatkan hipertrofi dan hiperfiltrasi glomerular. Proses ini menyebabkan peningkatan protein dalam urin. Kadar protein urin yang meningkat akan mempengaruhi aktivasi sel tubulus. Sel tubulus yang aktif akan mensintesis mediator inflamatori khususnya molekul khemokin dan endothelin, angiotensin II dan TGF $\beta$ (Schrijvers, 2004).

Molekul khemokin dan endothelin, angiotensin II dan TGF $\beta$ menyebabkan kerusakan pada membran basal tubular sehingga memudahkan masuknya produk dari tubular ke dalam interstisial dan kapiler peritubular. Timbunan protein di distal ginjal akan menghambat aliran urin serta memperparah kerusakan tubular interstisial dan extraceluler matrix (ECM) seperti kolagen, fibronektin dan laminin.

Bila nefron berakibat ati diabetik semakin parah, glomerulus yang rusak semakin banyak dan jumlah protein urin yang diekskresi lewat urin semakin meningkat. Selanjutnya akan terjadi penurunan fungsi ginjal, penurunan klirens kreatinin, glomerulosklerosis, fibrosis instrestisial dan akhirnya gagal ginjal terminal (Schrijvers et al, 2004; Bloomgarden, 2005).

\section{SIMPULAN}

Berdasarkan hasil penelitian dapat disimpulkan bahwa subyek penelitian dengan kadar glukosa urin antara $250 \mathrm{mg} / \mathrm{dL} \mathrm{s} / \mathrm{d}<500$ $\mathrm{mg} / \mathrm{dL}$ sebanyak 23 orang. Sedangkan kadar glukosa urin antara $500 \mathrm{mg} / \mathrm{dL} \mathrm{s} / \mathrm{d} 1000 \mathrm{mg} / \mathrm{dL}$ sebanyak 28 orang, sedangkan subyek penelitian dengan kadar protein urin antara negatif s/d 30 $\mathrm{mg} / \mathrm{dL}$ sebanyak 0 orang. Kadar protein urin antara $>30 \mathrm{mg} / \mathrm{dL}$ s/d $100 \mathrm{mg} / \mathrm{dL}$ sebanyak 20 orang. Sedangkan kadar protein urin antara $>100$ $\mathrm{mg} / \mathrm{dL} \mathrm{s} / \mathrm{d} 500 \mathrm{mg} / \mathrm{dL}$ sebanyak 31 orang.

Hasil penelitian juga menunjukkan terdapat korelasi/ hubungan antara kadar glukosa urin dengan protein urin pada penderita diabetes mellitus tipe II. Kekuatan korelasi yaitu: $r=1.000$ dengan persamaan $\mathrm{Y}=416,77-236 \mathrm{X}$ dapat 
digunakan untuk memprediksi besarnya pengaruh kadar glukosa urin dalam meningkatkan kadar protein urin, dimana $\mathrm{X}$ adalah kadar glukosa urin dan $\mathrm{Y}$ adalah kadar protein urin.

\section{DAFTAR PUSTAKA}

Bloomgarden ZT. 2005. Diabetic Nephropaty. Diabetes Care. Research Progressive Reviews.

Direktorat Laboratorium Kesehatan Direktorat Jendral Pelayanan Medik Departemen Kesehatan. 2005. Pedoman Pemeriksaan Laboratorium untuk Penyakit Diabetes Melitus. Jakarta.

Gandasoebrata, R. 2004. Penuntun Laboratorium Klinik. Edisi 11. Jakarta. EGC.

Guyton, Arthur C. 2007. Buku Ajar Fisiologi Kedokteran. Edisi 11. Jakarta. EGC.

Hastono, SP. et al. 2008. Statistik Kesehatan. Jakarta. Raja Grafindo Persada.

Mengko, Richard. 2013. Instrumentasi Laboratorium Klinis. Bandung. Teknik Biomedika ITB.

Moerdowo. 2002. Spektrum Diabetes Melitus. Jakarta. Djambatan.
Perkeni. 2006. Konsensus Pengelolaan Diabetes Mellitus.

Peterdi, J.P., Kang J.J., Toma, I. 2008. Activation of the renal renin-angiotensin system in diabetes new concepts. Neprol Dial Transplant. Suppl 23; 3047-3049.

Ritz, E., Keller C, Kristian H., Bergis. 2000. Nephropathy of type II diabetes mellitus. Neprol Dial Transplant. Suppl 9; 38-44.

Schrijvers B.F., de Vriese A.S., Flyvbjerg A. 2004. From Hyperglycemia to Diabetic Kidney Disiese : The Role of Metabolic, Hemodynamic, Intracellular Factors and Growth factors/Cytokines Endocrine Reviews. 25 (6): 971-1010.

Sudigdo, S. \& Ismael, S. 2011. Dasar-Dasar Metodologi Penelitian Klinis. ed 4. Jakarta. Sagung Seto. 